\title{
Diagnosing Thermal Behaviour of the Administration Block of the University of Colombo for Retrofitting Passive Design Strategies
}

\author{
Nadeeka Jayaweera and Upendra Rajapaksha \\ Faculty of Architecture, University of Moratuwa \\ nadika1982@yahoo.com,rajapaksha_upendra@yahoo.com
}

\begin{abstract}
Existing non-domestic buildings in developing countries account for a substantial percentage of energy usage for indoor climate control and therefore contribute to carbon dioxide emissions. High levels of air temperatures associated with radiation in warm-humid climates contribute to heat gain and thus indoor overheating conditions and indoor thermal discomfort. These trends have contributed to introducing active systems in building operation resulting in increase of energy consumption. The method used in the study involved on site investigations of thermal behavior of commercial office buildings in urban warm humid climates in Sri Lanka. Literature showing that thermal behavior of building microclimates, form and envelope are important design variables which can act as modifiers of outdoor climate into favorable indoor climates in buildings. The study evaluates the potential of these variables in maintaining indoor thermal comfort. Based on the thermal analysis of the building and immediate surroundings a retrofitting proposal was developed to improve building thermal performance
\end{abstract}

Key Words: Energy Consumption, Retrofitting, Thermal Comfort, Warm-humid Climate

\section{Background}

The condition of buildings makes a significant impact on its energy consumption. Old building tends to use energy more inefficiently than new buildings. The energy efficiency of buildings is a challenge for developing countries like Sri Lanka which do not possess any kinds of fossil fuels for electricity generation. Colombo is the most problematic city in Sri Lanka in this regard with a monthly consumption of average $649 \mathrm{kwh} /$ cons (CEB Annual Report, 2007). Non-domestic buildings are the main electricity consumers in Colombo accounting for $73 \%$ of the total consumption (CEB Annual Report, 2007). Therefore, to reduce the demand on electricity consumption in Colombo large existing buildings stocks have to be addressed.

In developing countries like Sri Lanka, the most viable option for optimizing energy use is through the implication of passive designs in buildings as they do not incur a large capital or maintenance cost. Therefore, to explore the possibilities of sustainable measures for existing buildings a comprehensive study was conducted which could lead to the identification of passive design strategies suitable for existing buildings in a hot-humid climate.

\section{Literature Review}

Energy in the operational stage in a building is primarily used for indoor climate modification which involves thermal comfort, visual comfort and noise control.

Of the above three, in Colombo, the greater part of the energy is used to achieve thermal comfort due to the hot-humid conditions year round. Visual comfort in Sri Lanka is not difficult to achieve due to conformity of the tropical sun path throughout the year and therefore sunlight is equally and fully distributed. Noise control is a new challenge in the urban context but not much of energy is consumed by buildings at present in order to relieve the problem. Hence, considering the 
above issues, achieving thermal comfort is the main challenge in the local context.

Givoni (1969) states that 'Thermal comfort can be defined in a negative sense, as the absence of irritation and discomfort due to heat or cold, or in a positive sense, as a state involving pleasantness' (Givoni, 1969, pp 47). Thermal comfort is a state of the mind as described above. The condition of the mind depends on physical as well as psychological aspects of the environment that is affecting the person. Therefore, it is a state that is achieved using different strategies in different environment. Thermal comfort modification in hot-humid region deals with controlling of the two environmental factors, i.e. heat gain and humidity.

Due to the high temperatures and humidity year round, heat dissipation from the body does not reach a desirable level to achieve thermal comfort in hot-humid climates. This is one of the common problems when designing comfortable built environments in the tropics. In the tropics high humidity and temperatures are almost equal to the temperature of the human body (Koenigsberger, 1973). Therefore, movement of air is very important because it can aid some moisture of the body to precipitate and create a sense of thermal comfort. Air speed is an important factor in determining comfort in a building as shown in Olgaly bio-climatic chart.

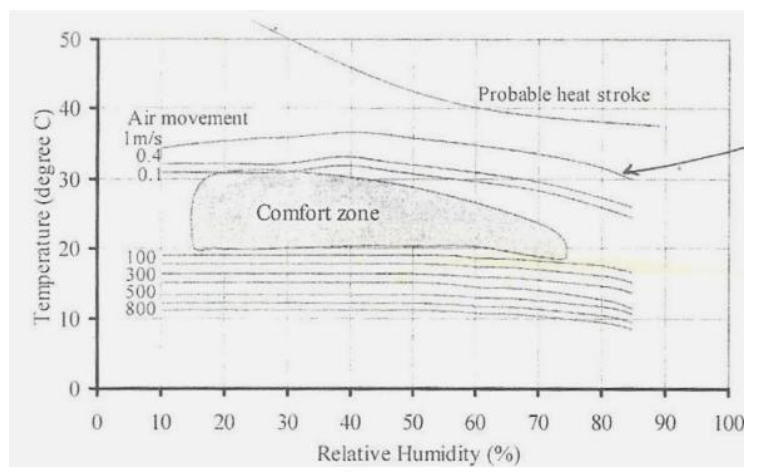

Chart 1: Olgly's Bio-climatic Chart (1953:20)

Thermal comfort for occupants of buildings is a paramount responsibility of architects and engineers. In many buildings thermal comfort and visual comfort are not achieved by passive means therefore, the bulk of the operational energy of buildings is used to achieve desired comfort level. Givoni (1969) also states that the complex interaction and feedback exist between the buildings and their outdoor environment. On one hand, the indoor climate and comfort conditions in any given building depend on the climate conditions surrounding the building. But, on the other hand, the building itself especially group of buildings modifies the climatic conditions surrounding it (Givoni, 1969, pp xii).

The microclimate depends on various influential factors in its environment. Modifying these factors affecting the microclimate to provide shading and promote air movement can improve the indoor comfort level.

\section{Landscape, Site Orientation and Surrounding Building Layout:}

Vegetation around a building has many benefits for the indoor climate. It is noted that shading from trees contributes to lower energy for cooling. Shaded surfaces have a much lower temperature and thus, decrease the rate of heat convection to the building interior (Olgyay and Olgyay, 1954, pp.157).

The current trend in the building and construction industry is covering the earth with 'impermeable and virtually inert tarmac and paved roof surfaces'. Robert and Brenda (1991) states that vegetation is an important indigenous aspect of place and therefore, is an important regionalist design factor besides being ecologically vital. It might also be argued that vegetation (and other biotic components of the location) needs to be introduced into the built environment in far greater abundance than is currently common (Brenda and Robert, 1991, pp.22).

Orientation of the building layout in relation to the wind direction and the sun path also has to be taken into consideration when considering building complexes, housing schemes, etc. Microclimates around same building are different on each side. In urban environments buildings do not stand alone. Buildings are cramped into small plots of lands with very little open space. Therefore, the impact of the surrounding building layouts and their orientation are vital factors in its microclimate. 


\section{Passive Solar Design:}

Shade can be borrowed from adjoining buildings into the site. The concept of Shadow Umbrella was formed by Dr. Rohinton Emanuel in the late 1990s. 'A three sided court with no buildings on the West will be the ideal, the West being the most orientation to shade the low latitudes' (Rohinton, 2004, pp.127).

\section{Air Movement:}

Spread out forms creates the necessary microclimate pockets around the building to promote air movement as opposed to a compact form that will trap the heated air inside (Givoni, 1998, pp 384).

Givoni (1998) proposes a breezeway through the entire plan of the house which will provide ventilation throughout the entire building. The optimal interior design in hot-humid regions is, according to Givoni, to have an open plan for the dwelling unit. An "open plan" implies locating various functions within an undivided space (Givoni, 1998, pp.389). An open plan can accommodate breezeway efficiency due to its lack of boundaries. Givoni suggests the use of furniture, movable partitions etc. Functions such as cooking, dining, study, and sleeping areas that go together should be located in interlocking spaces. In hot-humid climates it is wise to avoid prolong activities in the eastwest direction due to the direct sunlight during the course of the day.

\section{Porches and Verandahs:}

Porches and Verandahs should ideally be positioned in the West or East to avoid the direct sun light. Porches and Verandahs oriented to the South-West direction can avoid rain coming through the building in the monsoon seasons.

\section{Atriums and Transitional Spaces:}

Robert and Brenda (1991) states that large multi-storey transitional spaces might be introduced in the central and peripheral parts of the building due to air spaces and atriums. These are serving as in-between zones that are located between the interior and the exterior (Brenda and Robert, 1991, pp 29).

\section{Recessions:}

Deep recessions may provide shade on the building's hot sides. A window can be totally recessed to form a balcony or a small sky court that can serve a number of functions besides shading. Placing balconies on hotel elevations permits glazing to these areas to be full height clear panels. These can give access to the balcony spaces which can serve as evacuation spaces, as large terraces for planting a landscaping, ands as flexible zones for the addition of future facilities (Givoni, 1998, pp 29). As opposed to balconies deep recesses can also provide shade to the building especially in apartment complexes and other high-rise buildings.

\section{Wind Towers:}

The use of wind towers is not a common aspect in hot-humid regions due to the gaps in technology. The use of wind towers to provide wind-driven ventilation is most suited to building types such as open plan office building with an atrium or stair wells between floors (McCarthy, 1999, pp36).

\section{Wind Scoops:}

Wind scoops are designed to 'to catch' the wind and direct fresh air into the building. To operate effectively they must be omni directional turning into the wind. Fixed wind scoops quickly become ineffective if the wind is not directed head on to the scoop and will even work in reverse (McCarthy, 1999, pp29). To enhance the effects of wind-driven ventilation there are two systems: wind towers and wind scoops. The object of a wind tower is to draw air out of a building, encouraging natural air flow. Wind scoops are designed to draw air into a building. A combination of wind scoops and wind towers can create effective air movement inside a building by capturing and extracting air simultaneously.

\section{Shading:}

Steven Szokolay (2004) describes the building envelope as a fuzzy line often dissolving into various transitional spaces. And emphasizes the role of the envelope as a selective filter to admit desirable and exclude adverse influences (energy flows) from and to the indoor environment (Chang and Chou Chiang, 2004, pp 29). 
Internal shading devices including venetian blinds, roller blinds, curtains, etc usually retractable, i.e. can be lifted and rolled or drawn back from the window, but some are only adjustable in their angle (Givoni, 1969, pp 29).

\section{Fins and Overhangs:}

Overhangs are used to protect the opening from direct sunlight as well as the rain. Overhangs cast shadows that shade the opening but due to the path of the sun the effectiveness of it may vary throughout the year. Therefore, an opening protected by the morning sun many be only partially protect in the afternoon.

To solve this issue technological developments have resulted in creating movable overhangs that provide protection from the sun daily. Fins are vertical shading devices. Sun light enters a building from all directions. To block off sunlight that comes from the sides vertical shades called fins are used in many buildings.

\section{Innovative Skins and Second Skins:}

Good thermal insulation of the building skin reduces heat transfer both from solar gain and loss of coolness from the inside. A second skin (a rain wall) can be built over the inner wall with an air gap in between (Givoni, 1998, pp31).

A second skin is independent of the building envelope but can have a significant impact of the interior thermal and visual comfort level. As it does not depend on the structure of the building, it can be easily implemented than other strategies with little or no restructuring of the existing building. Its primary function is to shade the building and promote air flow. It can regularize the outdoor environment and clear out of dust before entering the building more effectively.

'A water-spray system on hot facades promotes evaporation and therefore, cooling' (Brenda and Robert, 1991, pp31). In tropical countries a second skin with high thermal mass can protect the building envelope. The gap between the skins can act as a courtyard while becoming a chimney for the stack effect.

\section{Materials:}

Materials play an important role in a building that is naturally ventilated. 'The climatic role of materials in un-air conditioned, naturally ventilated buildings in hot humid regions, is to minimize solar heating of the interior during daytime and to maximize the rate of cooling during the evening and night hours' (Givoni, 1998, pp397).

Physical properties of the materials used for the building envelope decides the building envelopes filtering capacity of the outside elements into the building. In hot-humid climate thick walls are used in construction to reduce heat gain in to interiors. But at night time the stored heat cannot be dispersed efficiently as night time temperatures are too high.

Therefore, there is a contradiction regarding the thermal mass recommended for the tropics. '...because the temperature of the outside air remains almost the same throughout the day and night, a building cannot cool off sufficiently at night-time to allow the storage of heat during the day. The principle of thermal storage cannot be relied on this climate. It is, in fact, advisable to construct buildings are low thermal capacity materials, using lightweight construction' (Givoni, 1998, pp 397). It can be stated that areas functioning at night time to be enveloped in low thermal capacity structures while day time activity spaces should have a high thermal mass cover. A case study by B. Givoni has concluded the following:

'If the building is of low mass, indoor temperature will rise dramatically during daytime and reach its maximum in early afternoon. Then it will cool down rapidly by natural ventilation at night even with very light winds. On the other hand, if the building is high-mass, maximum indoor temperature is suppressed at daytime, but the stored heat in mass will re-radiate back to the space at night, which will cause much higher temperature during night hours. Therefore, when compare the different thermal profiles wit occupancy pattern, low-mass construction seem to be a low-mass construction seem to be a better choice' (Ignjatovic N. and Ignjatovic D, 2004, pp 534). 
B. Givoni also states that 'However, recent research has demonstrated that if effective night ventilation can be ensured by the provision of exhaust fans, high mass buildings can be more comfortable especially during daytime hours , than lightweight buildings.' construction' (Givoni, 1998, pp 397).

\section{Texture:}

A smooth surface can directly reflect sunlight than textured surface that will diffuse it. Therefore, a smooth surface is more suitable for the tropics for maximum heat reflection.

\section{Colour:}

Colours have different heat absorption capacities. Dark colours absorb more heat than Light colours. Therefore, to avoid excess heat gain into a building light colours are used. Givoni (1998) has performed many case studies to test the effect of colour on heat gain in buildings.

A study in Hong Kong by Givoni has concluded the following: 'Maximum air temperature inside an unventilated and nowindow room could be more than ten degrees higher when it was in dark than in white colour. Therefore, application of light surface colour is, indeed, the simplest, very effective, and economical means to reduce indoor temperature in hot-humid climate.' (Givoni, 1998, pp534).

\section{Transparency and Opacity:}

Transparent materials such as glass, PVC sheets can directly send through unfiltered light and heat into a building when it is being used as glazing or roof light. The heat gain capacity of these materials decreases as the opacity increases.

Opaque materials tend to diffuse light and cause glare, making it uncomfortable for the occupants though it has less heat gain capacity. Trees can cut-off glare effectively. Many world renowned structural glass companies have come up glasses that only send sunlight without the heat into a building, making glass more environmentally popular. Electronically controlled tinted glass is one of the few modern glass technologies that are available at a high price today. There are many methods to make buildings sustainable by passive design strategies as taken in to account the above literature survey.

\section{Existing Form, Function and Spaces of the Case Study: Administration Block, Colombo University}

The administration block for the Colombo University was constructed in the early 80's by Thuraraja Architects to house the administration facilities of Colombo University. The Administration Block is a building that has a compact and deep plan form. It has four identical floors. Each floor has a $1090 \mathrm{~m}^{2}$ floor area adding up to a total floor area of $4360 \mathrm{~m}^{2}$.

The building plan is square in shape with a central courtyard that appears to be too small. The interior has mostly an open plan layout in both wings of the building later divided by wood or aluminum partitions. A narrow balcony runs along the façade of the building on three sides except on the west. Corridors along the courtyard function as the circulation space.

The administration block has many divisions. The Second and third floor are currently fully air-conditioned. Other floors are equipped with ceiling fans to promote air movement. The interior of the building is well lit with fluorescent lights. The windows are covered with thick curtains or with vertical blinds to avoid direct sunlight.

The compact building form and internal open plan exhibits characteristics of modern Architecture which was prominent in the 70's when the building was designed. The repetitive elements of the facade, the white exterior, Slab roof (though originally it was designed as a hipped roof) tie it even closer to the modern era of Architecture.

Wall partitions are of single brick work or of Aluminium framed partition. The partitioning of the spaces was done in later stages; hence different divisions have different partition styles. Every workstation does not operate a computer. The interior of the offices appear to be spacious and the internal layout is functioning well. 


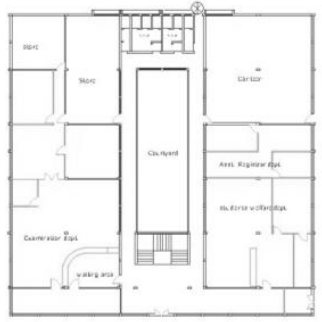

Ground floor

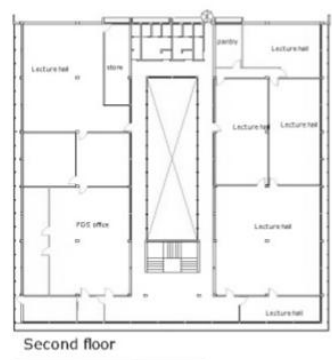

Figure 1: Interior Layout Plans

The monthly electricity consumption breakdown of the Administration Block is as follows:

\begin{tabular}{|c|c|c|c|}
\hline $\begin{array}{c}\text { Billing } \\
\text { month }\end{array}$ & $\begin{array}{c}\text { Units } \\
\text { consumed }\end{array}$ & $\begin{array}{c}\text { KVA } \\
\text { Demand }\end{array}$ & $\begin{array}{c}\text { Total } \\
\text { (Rs.) }\end{array}$ \\
\hline January & 16,949 & 130 & $308,241.19$ \\
\hline February & 21,148 & 127 & $363,415.68$ \\
\hline March & 16,734 & 120 & $297,553.44$ \\
\hline April & 19,534 & 127 & $504,518.40$ \\
\hline May & 22,152 & 146 & $512,882.41$ \\
\hline June & 17,239 & 130 & $409,767.66$ \\
\hline July & 19,867 & 130 & $462,042.80$ \\
\hline August & 18,794 & 127 & $435,414.36$ \\
\hline September & 18,908 & 128 & $438,209.52$ \\
\hline October & 20,731 & 130 & $482,164.14$ \\
\hline November & 23,349 & 130 & $519,381.06$ \\
\hline December & 18,350 & 130 & $429,699.00$ \\
\hline
\end{tabular}

Table 1: Electricity Use in Administration block in Year 2008

Source: Annual Electricity Use Report, Maintenance Department, University of Colombo

Table 1 clearly states that the administration block has a monthly average bill of Rs.430, 000, which is very high for a four storey building with a total square area of $4360 \mathrm{~m} 2$. Hence this building falls into the category of a high energy consuming building in Colombo that could benefit from energy optimization.
After a preliminary survey of the location of the building the administration block of the Colombo of University was selected as the case study.

\section{Methodology}

The methodology used is divided into two distinct parts. One, is the analysis of the present state of the building, two is the proposal of a number of passive design strategies for retrofitting. The Building analysis includes a description of the Architectural features, thermal and visual comfort of the building as well as of the Macroclimatic analysis is based on data of the meteorological department. The Microclimate around the building plays significant role in achieving thermal comfort inside. The analysis of environmental conditions in the microclimate comprised of field air temperature and Humidity measurements with the use of data loggers. Temperature and relative Humidity values were recorded from 10a.m.-4.30p.m on the 20th of February 2009. The analysis of the environmental conditions in building interior was based on air Temperature and Humidity measurements with the use of the data loggers. Temperature and relative Humidity values were recorded from 9a.m.-.5.00p.m on the 21st of February. An examination of the existing passive design strategies is conducted based on the design guidelines.

The design proposal is given based on the results of the investigation on site as well as the application of the design guidelines chart (score card) for the existing building. The design solutions consist of a combination of strategies that are suitable for the administration block taking into account its existing architecture, structure, materials etc., however the retrofitting proposal needs further investigations to assess its performance.

\section{Building Microclimate}

The analysis of the environmental conditions in the microclimate comprised field air temperature and humidity measurements. Temperature and relative humidity values were recorded from 10a.m.-4.30p.m on the 20th of February. 


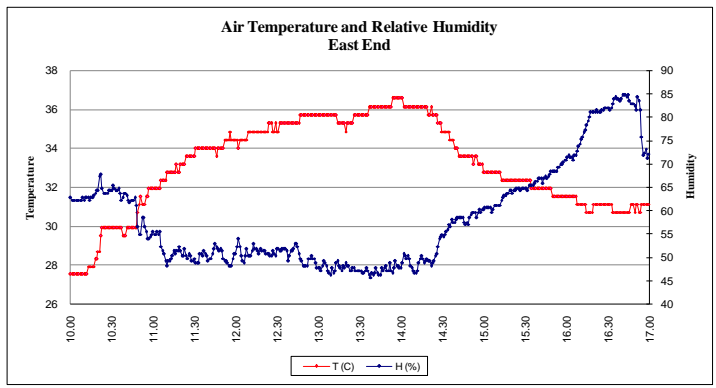

Graph 1: Air Temperature and Relative HumiditynoFiast Find

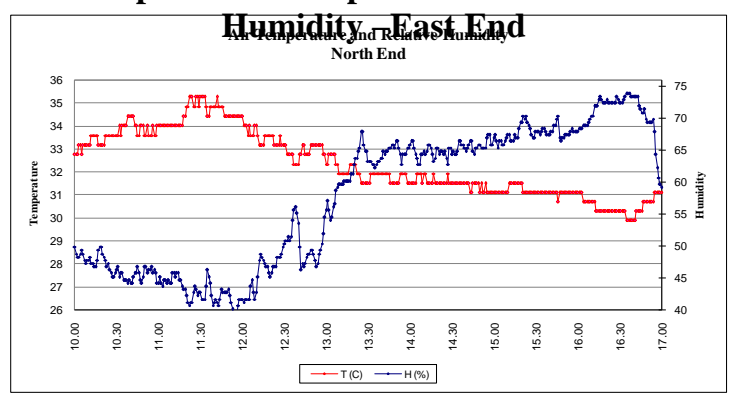

Graph 2: Air Temperature and Relative Humidity -West End

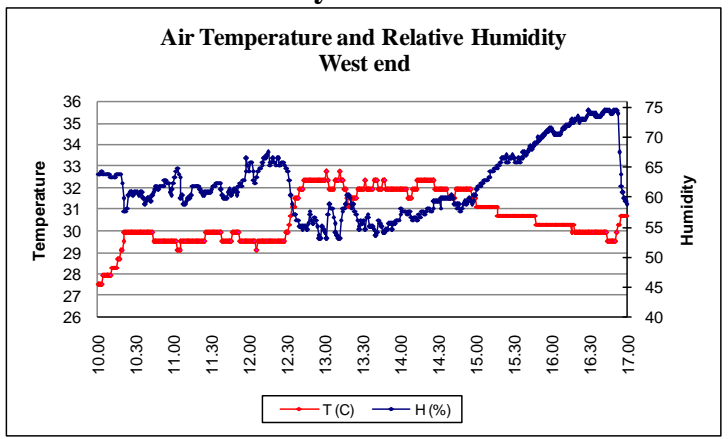

Graph 3: Air Temperature and Relative Humidity -North End

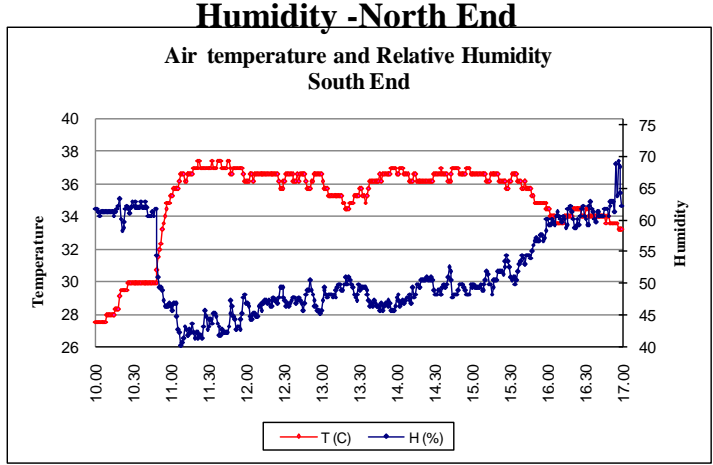

Graph 4: Air Temperature and Relative Humidity-South End

Shadows cast by the surrounding buildings and by trees too have an impact on the micro climate of the building. Shading can reduce the air temperature of a space due to the obstruction of direct sunlight.

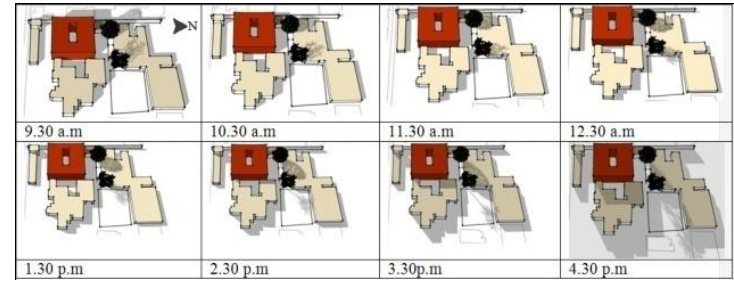

Figure 2: Shadow Casting of the Surrounding Buildings and Vegetation at Different Times of the Day

\section{Wind Speed and Direction}

Wind speed is less than anticipated in all directions. This has resulted in an uncomfortable micro environment around the building. The Administration block is surrounded by built environment in either direction further hindering the wind movement.

\begin{tabular}{|l|l|}
\hline Location & Wind Speed \\
\hline North end & $\begin{array}{l}\text { varies between 0.61-0.64 } \\
\mathrm{m} / \mathrm{s}(\text { multi directional) }\end{array}$ \\
\hline South end & $\begin{array}{l}\text { varies between 1-1.67 } \\
\mathrm{m} / \mathrm{s}(\text { multi directional) }\end{array}$ \\
\hline East end & $\begin{array}{l}\text { varies between 0.08 - } \\
0.68 \mathrm{~m} / \mathrm{s}(\text { multi } \\
\text { directional) }\end{array}$ \\
\hline West end & $\begin{array}{l}\text { varies between } 1.25- \\
0.89 \mathrm{~m} / \mathrm{s}(\text { multi } \\
\text { directional) }\end{array}$ \\
\hline
\end{tabular}

Table 2: Wind Flow Rates for the Microclimate

The building is constructed in a linear angle to the college with a very small gap that prevents wind movement for the east. The microclimate wind speed is very low does not help promote air movement inside the building.

\section{Microclimate Analysis}

- The Southern end of the building is the hottest while the west end is relatively cool. Generally the Temperatures around the building are very high proving to be a serious problem in achieving thermal comfort indoors.

- The microclimate of the building has a temperature variation of $28^{\circ} \mathrm{C}-35^{\circ} \mathrm{C}$ which is above the stipulated comfort level.

- The shadow cast by the boundary wall has affected the temperature of the West end. West end records the lowest 
temperatures in the microclimate being well shaded.

- The microclimate wind speed is very low does not help to promote air movement inside the building.

\section{Central Courtyard}

The court yard has a different behaviour pattern in relation to temperature and humidity in the micro environment.

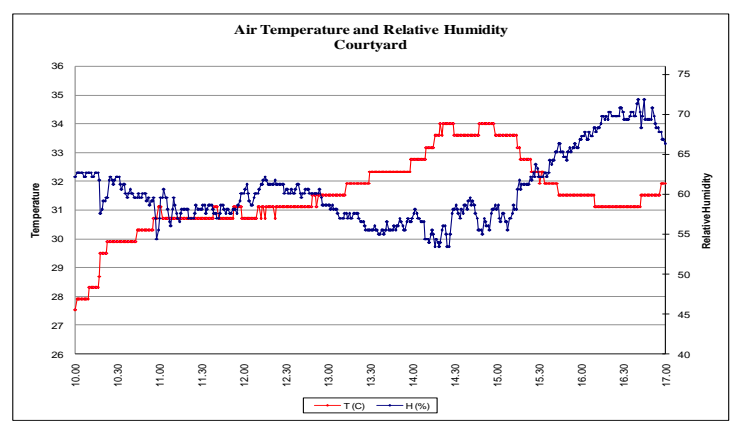

Graph 5: Air temperature and relative Humidity for the Courtyard

The temperature in the courtyard slowly rises and peaks at $2.00 \mathrm{pm}$. The courtyard reaches a peak temperature several hours after the outside temperatures have peaked.

\section{Wind Speed and Direction}

Wind speed in the courtyard too is not adequate. Wind speeds were around $0.05 \mathrm{~m} / \mathrm{s}$ during $11 \mathrm{a} . \mathrm{m}$ and at 3p.m. (wind speed taken on 21.02.09)

\section{Central Courtyard Analysis}

- The main purpose of having a courtyard is to promote ventilation. The courtyard does not promote heat removal through air movement which is evident by the thermal analysis. But in this scenario it is visible that the temperatures are above comfort levels (comfort level being 26$28^{0} \mathrm{C}$ ).

- The depth of the courtyard also makes it difficult for light to reach the work areas in the building. Direct sunlight reaches the workspaces during noon. The heat that comes with the sunlight gets trapped in the narrow courtyard heating the building further.

\section{Indoor Environment}

The analysis of the two wings (north and south) of the building was conducted in separately. The analysis comprised of air temperature and Humidity data obtained through a field investigation in the North and South wings of the building and the courtyard.

\section{Air Temperatures of the North Wing}

The following charts consist of the North wing indoor air temperature, Central Courtyard air temperature and North end microclimate air temperature for a comparative analysis.

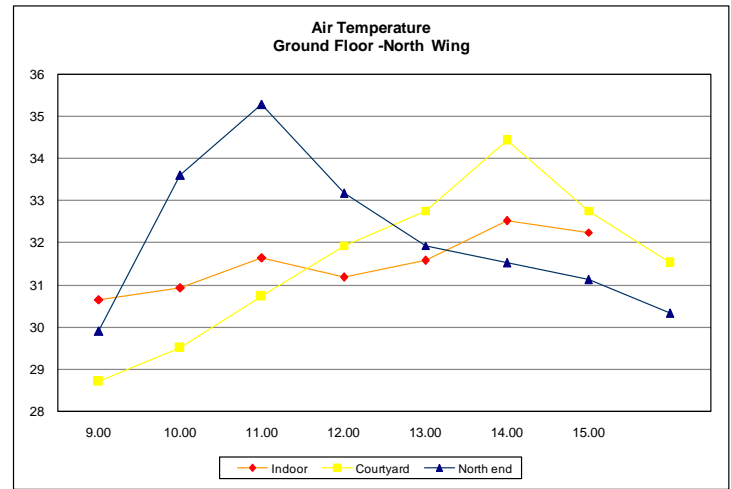

Graph 6: Air Temperature and Relative Humidity -North Wing-Ground Floor

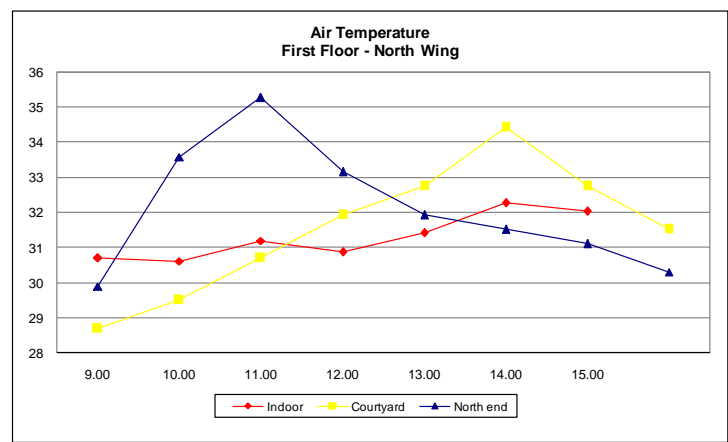

Graph 7: Air Temperature and Relative Humidity -North Wing-First Floor

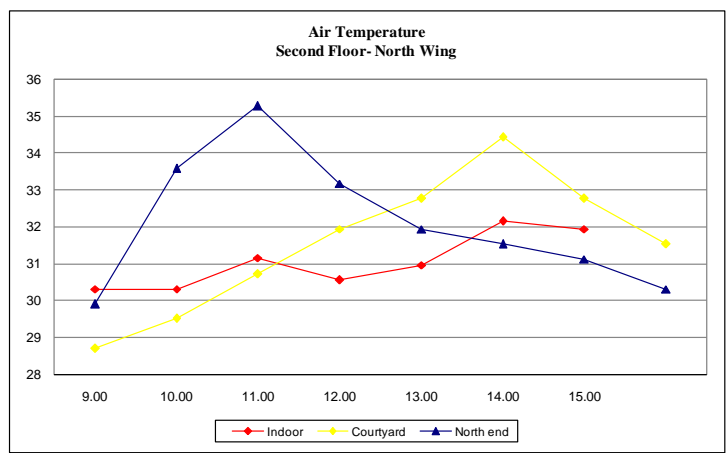

Graph 8: Air Temperature and Relative Humidity -North Wing-Second Floor 


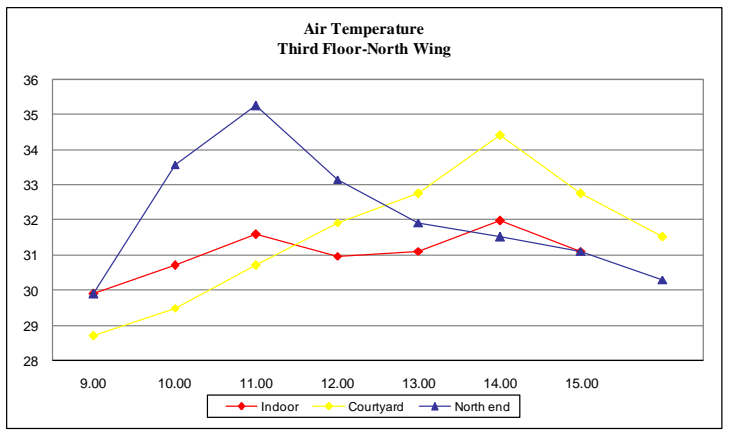

Graph 9: Air Temperature and Relative Humidity -North Wing-Third Floor

Air temperature patterns on all floors are very similar. The temperatures on floors peak twice during the day, these peaks correspond to air temperatures in the north end and the courtyard. From the above chart it is visible that the North wing of the building is subject to overheating from $1.00 \mathrm{pm}$ to $4.00 \mathrm{p} . \mathrm{m}$ overheating of a building is one of the main causes for thermal discomfort.

\section{Air Temperatures of the South Wing}

The analysis of environmental conditions in the indoor environment comprised air temperature and Humidity measurements with the use of Hobos in the North and South wing of the building, the corridors and the courtyard. Temperature and Relative Humidity values were recorded from 9.00a.m.-4.30p.m on the 20th of February.

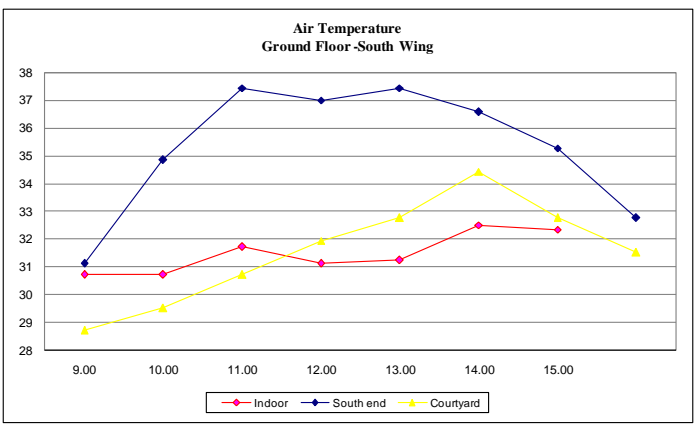

Graph 10: Air Temperature and Relative Humidity -South Wing-Ground Floor

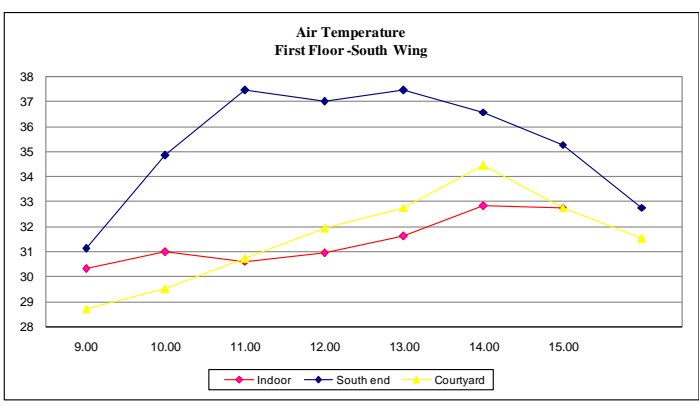

Graph 11: Air Temperature and Relative Humidity -South Wing-First Floor

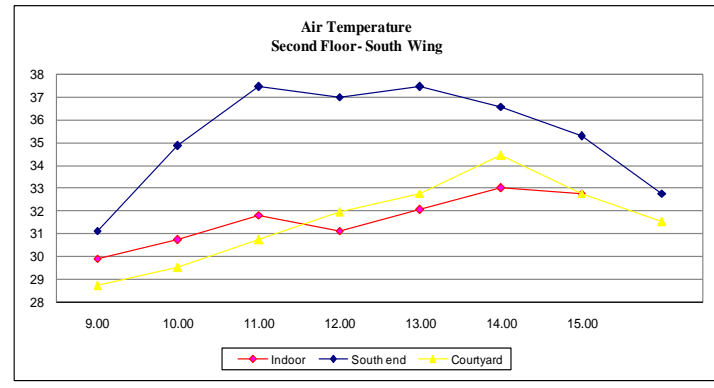

Graph 12: Air Temperature and Relative Humidity -South Wing-Second Floor

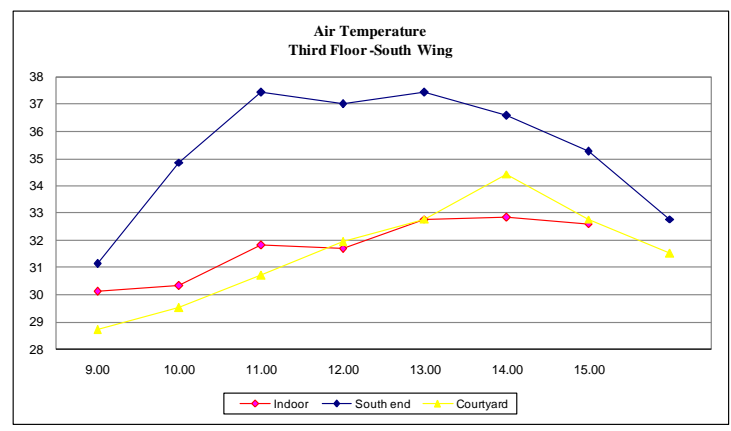

Graph 13: Air Temperature and relative Humidity-South Wing-Third Floor

Air temperature patterns on all floors are very similar. The temperatures on floors peak twice during the day, these peaks correspond to air temperatures in the South end and the courtyard. From the above charts it is visible that the South wing recorded the highest temperatures.

\begin{tabular}{|l|l|l|}
\hline & North Wing & South Wing \\
\hline Ground & varies between & varies between \\
floor & $0.1-0.78$ & $0.15-$ \\
& $\mathrm{m} / \mathrm{s}($ multi & $1.33 \mathrm{~m} / \mathrm{s}$ (multi \\
& directional) & directional) \\
\hline First & varies between & varies between \\
floor & $0.49-0.63$ & $0.35-$ \\
& $\mathrm{m} / \mathrm{s}($ multi & $0.25 \mathrm{~m} / \mathrm{s}(\mathrm{multi}$ \\
& directional) & directional) \\
\hline Second & varies between & varies between \\
floor & $0.3-1.46$ & $0.26-$ \\
& $\mathrm{m} / \mathrm{s}($ multi & $0.14 \mathrm{~m} / \mathrm{s}($ multi \\
& directional) & directional) \\
\hline Third & varies between & varies between \\
floor & $0.4-$ & $0.41-$ \\
& $1.79 \mathrm{~m} / \mathrm{s}(\mathrm{multi}$ & $0.22 \mathrm{~m} / \mathrm{s}(\mathrm{mult}$ \\
& directional) & directional) \\
\hline
\end{tabular}

Table 3: Indoor wind speed and direction for the North and South wing 
The indoor wind movement is less than the adequate amount. If the temperature cannot be controlled at the above levels $\left(26^{\circ} \mathrm{C}-28^{\circ} \mathrm{C}\right)$ then air movement inside the building has to be maintained at $1.8 \mathrm{~m} / \mathrm{s}$ to achieve thermal comfort which has not occurred.

\section{Indoor Climate Analysis}

- The temperature rises from 9.00am steadily and peaks between 1.00p.m$2.00 \mathrm{p} . \mathrm{m}$ in all floors in both wings.

- The bio-climatic chart shows that the comfort zone for Colombo is temperature from $26^{\circ} \mathrm{C}-28^{\circ} \mathrm{C}$ with Relative Humidity at $65 \%$ in the absence of Air movement. This criterion is not met by the North or South wing of the building.

- The south wing indoor air temperature pattern follows the north wing temperature pattern closely. The temperatures on floors peak twice during the day, these peaks correspond to air temperatures in the South end and the courtyard.

- The significant difference between the two wings is the higher temperature recorded in the South wing than the North wing temperature.

- The North wing of the building is subject to 'over heating' from $1.00 \mathrm{pm}$ to $4.00 \mathrm{p} . \mathrm{m}$ over heating of a building is one of the main causes for thermal discomfort in the building.

- The South wing of the building recorded the highest temperatures.

- Due to the fact the windows are shaded with thick curtains; the lighting levels are very low inside the building. This resulted in the both wings being artificially lit throughout the day.

- The indoor wind movement is less than the adequate amount. If the temperature cannot be controlled at the above levels $\left(26^{\circ} \mathrm{C}-28^{\circ} \mathrm{C}\right)$ then air movement inside the building has to be maintained at $1.8 \mathrm{~m} / \mathrm{s}$ to achieve thermal comfort which has not occurred.

\section{Analysis Summary}

- The microclimate is very unfavourable to the building as it has high temperatures and low wind movement. The lack of shading, the obstruction of wind movement has caused an unpleasant outdoor climate around the building.

- The courtyard does not facilitate indoor cooling in the building as it has high temperatures and low wind movement. The purpose of the courtyard is to reduce temperature and to promote wind movement. Due to the depth of the courtyard and complete closure from all sides it does not function well.

- The thermal behaviour inside the building is diversified ranging from $29^{\circ} \mathrm{C}-33^{\circ} \mathrm{C}$. The impact of the courtyard and of the unfavourable microclimate keeps the temperatures above the stipulated thermal comfort level. $\left(26^{\circ} \mathrm{C}-28^{\circ} \mathrm{C}\right)$.

- The south wing indoor air temperature pattern follows the north wing temperature pattern closely. The temperatures on floors peak twice during the day, these peaks correspond to air temperatures in the South end and the courtyard.

- Air movement inside the building is less than $1.8 \mathrm{~m} / \mathrm{s}$. which is the recommended wind speed for temperature of $30^{\circ} \mathrm{C}$. The lack of wind is due to compact form of the building, poor performance of the courtyard, and the surrounding buildings.

- North wing is affected by overheating during 1.00 p.m to 4.00 p.m. Over heating in a building is a serious problem as it suggests the interior of the building is hotter than the exterior.

- The out-door temperature are very high due to the problems in the microclimate that the South wing temperature though more uncomfortable than the North wing is not over-heating. But the indoor is thermally uncomfortable at all times, as the temperatures area above the comfort limits and the air movement is low.

- Lighting levels has been reduced in order to avoid of heat gain in to the building. To reduce hear gain the windows are well shaded with thick curtains that cut off direct sunlight altogether.

- The corridors record higher temperatures than the interiors most of the time. The corridors are exposed to direct sunlight making it thermally uncomfortable. The cement parapet wall along the corridor makes the courtyard look even smaller. 
The above problems in the building can be to different reasons, one of the most likely causes being the building's climatic response. Using the design guidelines established for the microclimate, building form and envelope (from the literature review of the Research) the weak and strong aspects of passive design strategies in the existing building to identify the causes for thermal discomfort inside the building.

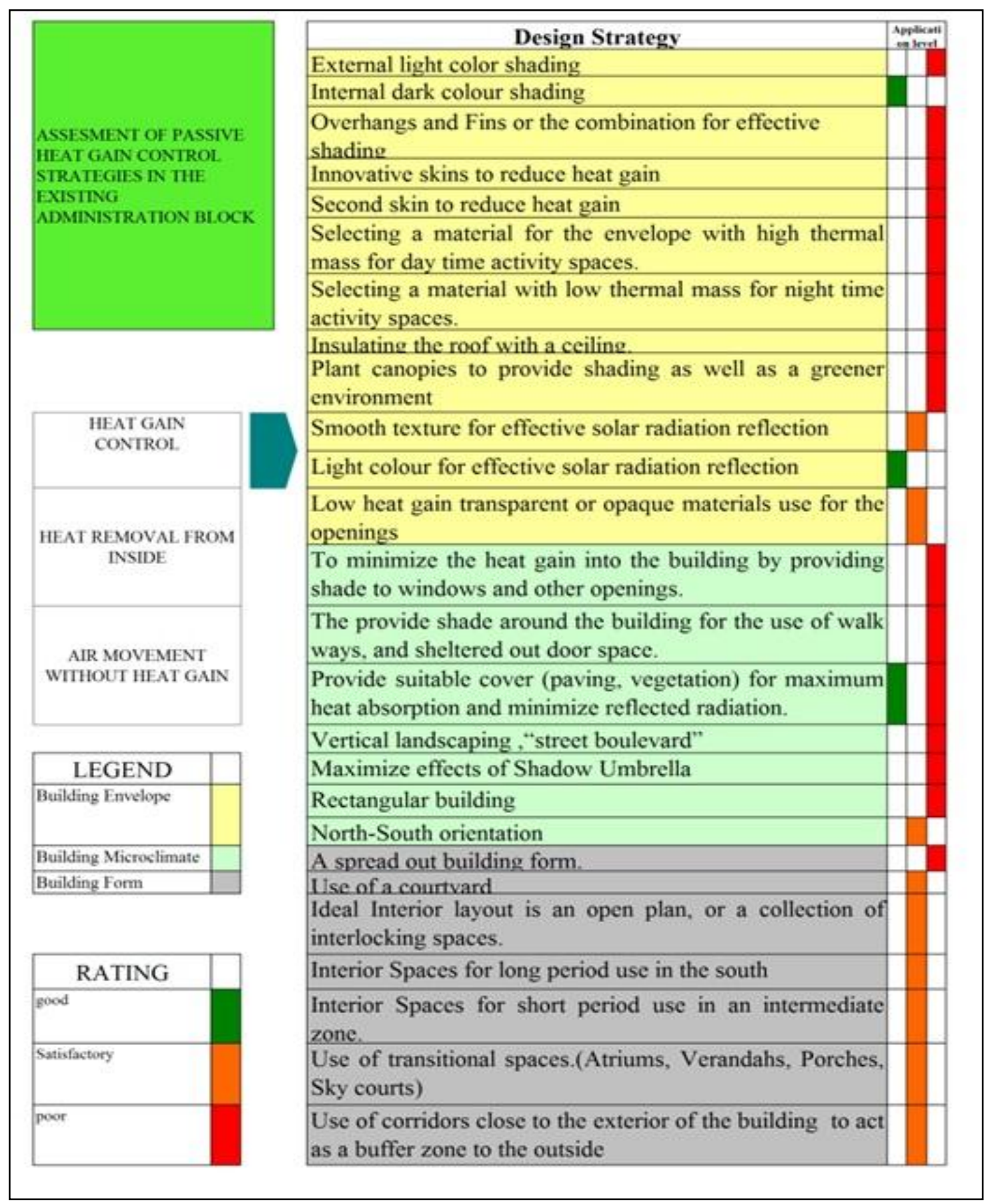

Figure 3: Assessment of Passive Heat Gain Control Strategies 


\begin{tabular}{|c|c|c|}
\hline \multirow{6}{*}{$\begin{array}{l}\text { ASSESMENT OF PASSIVE } \\
\text { HEAT REMOVAL } \\
\text { STRATEGIES IN THE } \\
\text { EXISTING } \\
\text { ADMINISTRATION } \\
\text { BLOCK }\end{array}$} & Design Strategy & \\
\hline & Openings oriented to the south & \\
\hline & Large openings & \\
\hline & Cross ventilation & \\
\hline & Innovative skins to facilitate heat removal from inside & \\
\hline & Second skin to facilitate heat removal from inside & \\
\hline & Plant canopies to provide shading as well as a greener environment & \\
\hline $\begin{array}{l}\text { HEAT GAIN } \\
\text { CONTROL }\end{array}$ & Louvers to continue indoor ventilation & \\
\hline $\begin{array}{c}\text { HEAT REMOVAL FROM } \\
\text { INSIDE }\end{array}$ & To optimize the use of the topography for natural air movement. & \\
\hline \begin{tabular}{|c|} 
AIR MOVEMENT \\
WITHOUT HEAT GAIN
\end{tabular} & To provide wind breaks, especially in front of the windows. & \\
\hline LEGEND & $\begin{array}{l}\text { Buildings to be constructed in non-linear pattern in different heights } \\
\text { to promote wind movement. }\end{array}$ & \\
\hline Building Envelope & A spread out building form. & \\
\hline \begin{tabular}{|l|l|l} 
Building Microclimatc \\
Building Form
\end{tabular} & The use of a breezeway. & \\
\hline & Use of a courtyard & \\
\hline & Interior Spaces for short period use in an intermediate zone. & \\
\hline RATING & Transitional spaces.(Atriums, Verandahs, Porches, Sky courts) & \\
\hline good & Use of corridors close to the exterior of the building. & \\
\hline $\begin{array}{l}\text { Satisfactory } \\
\text { poor }\end{array}$ & Wind scoops & \\
\hline
\end{tabular}

Figure 4: Assessment of Passive Heat Removal Strategies 


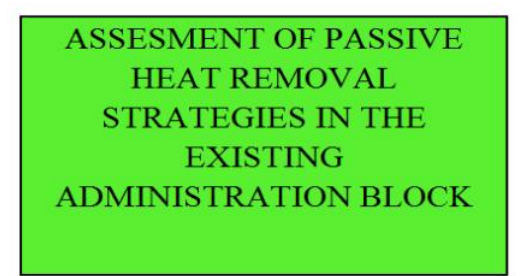

\begin{tabular}{|c|}
\hline $\begin{array}{c}\text { HEAT GAIN } \\
\text { CONTROL }\end{array}$ \\
\hline $\begin{array}{c}\text { HEAT REMOVAL FROM } \\
\text { INSIDE }\end{array}$ \\
\hline AIR MOVEMENT \\
WITHOUT HEAT GAIN \\
\hline
\end{tabular}

\begin{tabular}{|l|l|}
\hline \multicolumn{1}{|c|}{ LEGEND } & \\
\hline Building Envelope & \\
\hline Building Microclimate & \\
\hline Building Form & \\
\hline
\end{tabular}

\begin{tabular}{|c|c|}
\hline RATING & \\
\hline Good & \\
\hline Satisfactory & \\
\hline Poor & \\
\hline
\end{tabular}

\begin{tabular}{|l|l|l|}
\hline \multicolumn{1}{|c|}{ Design Strategy } & \multicolumn{2}{|c|}{$\begin{array}{l}\text { Application } \\
\text { level }\end{array}$} \\
\hline Openings oriented to the south & & \\
\hline Large openings & & \\
\hline Cross ventilation & & \\
\hline $\begin{array}{l}\text { Innovative skins to facilitate air } \\
\text { movement }\end{array}$ & & \\
\hline $\begin{array}{l}\text { Second skin to facilitate air } \\
\text { movement }\end{array}$ & & \\
\hline $\begin{array}{l}\text { Louvers to continue indoor } \\
\text { ventilation }\end{array}$ & & \\
\hline $\begin{array}{l}\text { Vertical landscaping "street } \\
\text { boulevard" }\end{array}$ & & \\
\hline $\begin{array}{l}\text { To optimize the use of the } \\
\text { topography for natural air movement. }\end{array}$ & & \\
\hline $\begin{array}{l}\text { To provide wind breaks, especially in } \\
\text { front of the windows. }\end{array}$ & & \\
\hline Maximize effects of Shadow & & \\
\hline A spread out building form & & \\
\hline The use of a breezeway. & & \\
\hline Use of a courtyard & & \\
\hline $\begin{array}{l}\text { Interior Spaces for short period use in } \\
\text { an intermediate zone. }\end{array}$ & & \\
\hline $\begin{array}{l}\text { Transitional spaces. (Atriums, } \\
\text { Verandahs, Porches, Sky courts) } \\
\text { Use of corridors close to the exterior } \\
\text { of the building. }\end{array}$ & & \\
\hline Wind towers & & \\
\hline Wind scoops & & \\
\hline
\end{tabular}

Figure 5: Assessment of Passive Air Movement Strategies 
The above analysis concludes that the building has very poor climatic considerations. It is understood therefore that the poor performance of the building in respect to thermal and visual comfort is caused by the building's poor climatic response. The absence of many passive design strategies has created an unpleasant working environment for the occupants as well a high electricity bill.

\section{Proposals for Retrofitting}

The above analysis concludes that the building has very poor climatic considerations. It is understood therefore that the poor performance of the building in respect to thermal and visual comfort is caused by the building's poor climatic response. The absence of many passive design strategies has created an unpleasant working environment for the occupants as well a high electricity bill.

Considering the Architectural character of the building and its existing structure, passive design modifications can be introduced to enhance the image of the building and make a more comfortable working environment.

\section{- Solutions for Heat Gain Control}

The envelope of the building presents the most number of failures in relation to the buildings climatic response therefore improving he envelope can have a significant effect of the indoor thermal comfort level.

External light color shading, overhangs, fins or the combination can be used for the envelope of the building to shade the openings. Internal shading devices (curtains and vertical blinds) that are already in use in the building also blocks the daylight coming in. hence it is not effective. Using external shading devices can block direct sunlight but also allow daylight to enter. Fins are the most suitable shading device for this building to reduce heat gain is the ideal solution for this building for many reasons.

There is enough space for additional construction on either side of the building. The fins can be structurally supported from the balcony which is not utilized as it is too narrow.

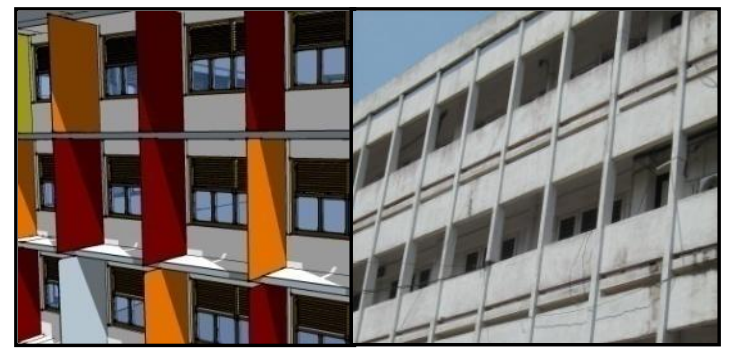

Figure 6: Proposed Building Façade with Vertical Fins

Figure 7: Existing Building Façade

All three facades are identical; therefore fins can be applied to all three sides without causing a significant change in the form. Using Colourful fins can uplift the image of the building as well as provide shading. To avoid heating up the courtyard during noon an opaque roof is introduced to the building that allows daylight without blocking the air movement.

\section{- Heat Output}

The heat that is pulled into the building with ventilation will heat the interior unless it is removed. The stack effect is employed in the retrofitting proposal to remove heat from the building interior into the courtyard. The air movement pattern is often reflected in the heat output as removing heat with the airflow is the most practical passive design solution. There is also the problem of lack of daylight entering from the courtyard into the building. The Courtyard appears to be small due to the brick parapet wall.

Replacing the brick parapet walls with light materials such as glass makes the courtyard and the corridor space more open and less confined.

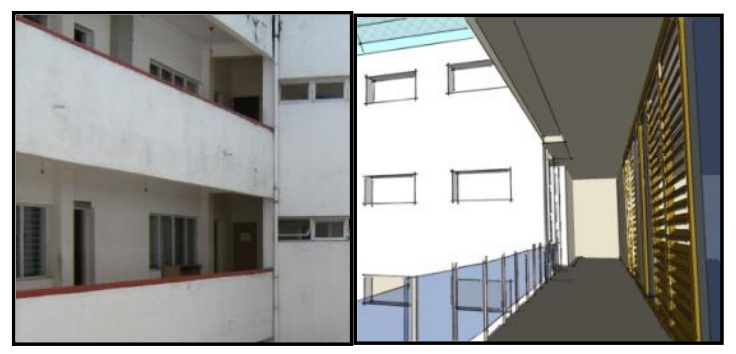

Figure 8: Existing Parapet Wall and Brick Walls Figure 9: Proposed Glazed Parapet Wall 
The North Wing and the South wing which is visually and physically detached from the courtyard can be reconnected with the use of translucent facades. Light from the courtyard does not reach the interior work spaces.

Therefore replacing the external walls facing the courtyard of the two wings with tinted glass can allow maximum day lighting into the building while reducing heat gain. It also uplifts the image of the building with lightness. A much more open space can be achieved by using a light partition facing the courtyard that gives the sense of a pleasant environment unlike the present covered dark working spaces.

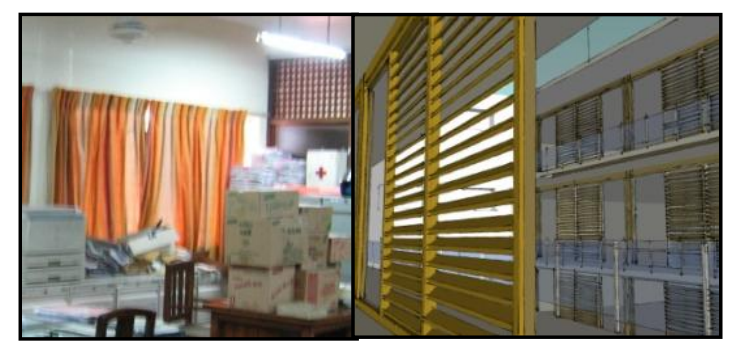

Figure 10: Existing Interior Spaces has No Connection to the Courtyard

Figure 11: Proposed Interior Spaces has Visual Connection to the Courtyard as well as Air Movement

Using full height glass tinted partitions can provide complete visual of the courtyard but also cut off glare and heat gain into the building. Retrofitting the brick wall façade facing the courtyard with Full height louvered openings can promote heat output into the courtyard and create a comfortable thermal environment in the work spaces.

\section{- Solutions for Promoting Air Movement}

The windows of the building are rarely opened and the louvers are not adequate to promote air movement into the building. Replacing the old windows with new designs can solve this problem. Tinted glass to be used for the windows to cut off heat instead of heavy curtains.

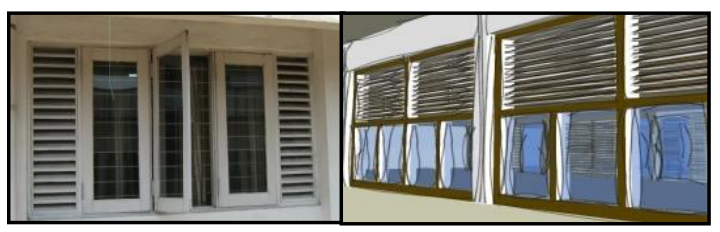

Figure 12: Existing window detail

Figure 13: Proposed Window design
The Proposed windows have louvers that provide constant air movement and covers $50 \%$ of the opening. The openable windows are small in size to reduce heat gain through glass but will provide adequate sunlight into the work spaces. The retrofitting passive designs allow air movement into the building without heat gain due to the external shading device. The openings are shaded at all times during the day. The building is ventilated throughout the day minimizing heat gain. A canopy above the courtyard avoids air entering the courtyard from the wind ward side, in order to promote hot air rising from the courtyard to the atmosphere. Though the building is used by the administrators of the university the canteen on the ground floor is used by the students. The canteen is situated in the path of the air flow. Therefore making the walls of the canteen permeable will open up the ground plan to a certain extent and promote wind flow into the courtyard. The Courtyard is covered from 4 sides with brick walls; therefore there is no lateral air movement. The stair case has a blind wall facing the Courtyard that can be removed to promote air circulation in the building. This will also provide a visual of the courtyard from the staircase.
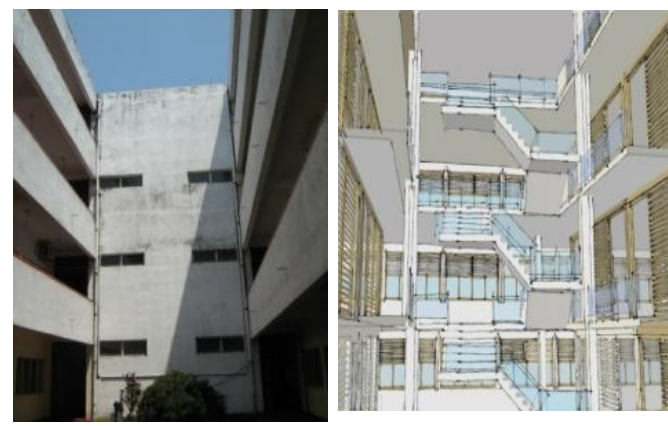

Figure 14: Courtyard is blocked from the east by the stair well wall

Figure 15: Opening up the staircase to the Courtyard

In the course of the study it was identified that the building Envelope is the most adaptable element of an existing building. Therefore should be considered first when retrofitting a building for sustainability. The Microclimate is adaptable to a certain extent. The building from is the most difficult due to practical reasons. 


\section{Further Directions}

Repeating the field investigations for longer time periods is required to confirm the findings in the building thermal behaviour. The design proposal for retrofitting using passive design strategies has to be tested through a thermal simulation to assess the impact of the design proposal in improving thermal behaviour of the case study building.

\section{Acknowledgement}

This research was conducted during the master's program at the Department of Architecture of the University of Moratuwa Sri Lanka. The authors thank late Mr. D.P.L.J. Nanayakkara the former acting registrar of the University of Colombo and Mr. R. Abeyrathne, Facilities Manager, University of Colombo and Mr. Chathura Masakorala, Technician, University of Moratuwa for their support extended during the study.

\section{REFERENCES}

Battle McCarthy Consulting Engineers. 1999. Wind Towers. Academy Editions.

Emmanuel, Rohinton M. 2004. An Urban Approach to Climate-Sensitive Design: Strategies for the Tropics. London: Spon Press.

Givoni, B. 1998. Climate Considerations in Building and Urban Design. John Wiley \& Sons, Inc. pp xii

Givoni, B. 1969. Man Climate and Architecture. London: Elsevier Publishing Company Limited

Hyde R., Thompson M., Watson S., Cheshire W. 2007. The Environmental Brief. Pathways to Green Design, London: Taylor and Francis.

Hyde R. 2000. Climate Responsive Design: A Study of Buildings in Moderate and Hot-humid Climate, London: E and FN Spon.

Intergovernmental Panel for Climate Change. 2007. Working Group 1 Report, The Physical Science Basis, available from: http://www.ipcc.ch/publications_and_data/publications_and_data_reports.shtml\#1

Intergovernmental Panel for Climate Change. 2007. Working Group 2 Report, Impacts, Adaptation and Vulnerability Available from: http://www.ipcc.ch/publications_and_data/publications_and_data _reports .shtml\#1

Intergovernmental Panel for Climate Change. 2007. Working Group 3 Report, Mitigation and Climate Change Available from: http://www.ipcc.ch/publications_and_data/publications_and_data_reports .shtml\#1

Koenigsberger O.H., T.G, Ingersoll, Alan Mayhew, S.V. Szoklay. 1973. Manuel of Tropical Housing and Building, Longman Group limited, p.218

Olgyay,V., Olgyay, A. 1954. Design with Climate: Bio-climatic Approach to Architectural Regionalism, New Jersey: Princeton University Press.

Robson D., Geoffrey Bawa. 2002. The Complete Works. London: Thames \& Hudson Ltd.

Santamouris, M. ed. 2001. Energy and Climate in the Urban Built Environment.

Susan Roaf, Andrew Horsley, Raj Gupta. 2004. Closing the Loop, Benchmarks for Sustainable Design. London: RIBA Enterprises Ltd.

The Energy and Resources Institute. 2004. Sustainable Building Design Manual Vol.2 : Sustainable Building Design Practices. New Delhi.

Vale, Brenda, Vale, Robert. 1991. Green Architecture: Design for a Sustainable Future. London: Thames and Hudson. 
Woolley T., Kimmins S., Harrison P., Harriosn R. 1997. Green Building Handbook. Volume 1. London: E\&FN Spon Press.

Yeang K.1994. Bioclimatic Skyscrapers. London: Artemis.

Castrejon A., Espinosa Castorena M.G. 2004. Recycled Architecture Passive Design Approach for Existing Buildings in Temperate Climates. Proceedings of PLEA. The Netherlands: Eindhoven.

Chang K.F., Chou P.C., Chiang C.M. 2004. A Study on the Sustainable Approaches for the Building Renovation in the Subtropical Region: Taking Kaohsiung City Hall as a Demonstration Project on the Energy-saving and Occupant-healthy Benefits, proceedings of PLEA. The Netherlands: Eindhoven.

Cukovic-Ignjatovic N., Ignjatovic D. 2004. Façade Refurbishment-Improving the Energy performance of the Existing Building Stock in Performance of the Existing Building Stock in Belgrade, Proceedings of PLEA, The Netherlands: Eindhoven.

Ganem, C. Coch, H. 2004. Building Envelope Design for a Zero Energy Response. Proceedings of PLEA. The Netherlands: Eindhoven.

Holcim Awards, 2005. Asia Pacific, Available from: http://www.holcimfoundation.org/T358/BronzeAirSuit.html.

Hyde, R.A., Yeang, K., Groenhout, N., Barram, F., Webster-Mannison., Healey,K. and Halawa, E., Abstract of Exploring Synergies with Innovative Green Technologies for Advanced Renovation using a Bioclimatic Approach

K. Lam, M.H, Miller, 2004. Assessing the Shading Performance of Climbing Plant Canopies, Proceedings of PLEA 2004, The Netherlands: Eindhoven.

Kiang B, Maneswaran U., Hong S. 2007. Naturally Ventilated Tall Office Building in the Tropics-learning from Bawa, Proceedings of PLEA 2007, The 24th Conference on Passive and Low Energy Architecture

Lichtbiau F. 2004. Solar Building and Renovation of the Existing Building Stock-an Example, Proceedings of PLEA 2004, The Netherlands: Eindhoven.

Looman R., Cauberg H. 2004. Climate-responsiveness of Building Elements, Proceedings of PLEA 2004, The Netherlands: Eindhoven.

Phdungsilp A., Martinac I. 2004. A Multi-Criteria Decision-Making method for the Retrofitting of Designated Buildings in Thailand, Proceedings of PLEA 2004, The Netherlands: Eindhoven.

Rajapaksha U. 2004. An Exploration of Courtyards for Passive Climate Control in Non-domestic Buildings. Unpublished PhD Thesis, University of Queensland, Australia.

Rajapaksha, U., and Hyde, R.A. 2002. 'Passive Modification of Air Temperature For Thermal Comfort In A Courtyard Building For Queensland,' in the Proceedings of the International Conference Indoor Air, Monterey, USA.

Triantia, E., Bougiatioti F., Oikonomou A. 2007. Retrofitting of the NUTA Students Residence Building with the use of an Innovative Aluminum "Skin", Proceedings of PLEA, The 24th Conference on Passive and Low Energy Architecture.

Cheng, E., Givoni. B. ___. Effect of Envelope Colour and Thermal Mass on Indoor Temperatures in Hot humid Climate. (Unpublished). 